\title{
PENGARUH KOMBINASI PUPUK KANDANG DAN NPK TERHADAP PRODUKSI SEGAR DAN RASIO DAUN DAN BATANG RUMPUT GAJAH MINI DEFOIASI KE-3
}

\author{
Dharmaseno Valgunadi ${ }^{\mathrm{a}}$, Bahrun ${ }^{\mathrm{b}}$, Nur Hidayat ${ }^{\mathrm{c}}$ dan Adi Fathul Qohar ${ }^{\mathrm{d}}$ \\ ${ }^{a, b, c}$ Fakultas Peternakan, Universitas Jenderal Soedirman, Purwokerto \\ ${ }^{d}$ Program Studi Peternakan, Universitas Ma'arif Nahdlatul Ulama Kebumen, Kebumen
}

Surel: adifathulqohar@umnu.ac.id

\begin{abstract}
ABSTRAK
Tujuan dari penelitian ini adalah untuk menguji pengaruh pemberian pupuk kandang dan pupuk NPK dengan penggunaan dosis pupuk yang optimal pada rumput gajah mini. Bahan yang digunakan dalam penelitian ini adalah 720 batang stek rumput, $270 \mathrm{~kg}$ pupuk kandang, 2,5 kg pupuk NPK. Metode yang digunakan adalah eksperimen pola faktorial dengan desain kelompok acak. Faktor pertama adalah pupuk kandang yang terdiri dari pupuk K0: pupuk $0 \mathrm{~kg} / 5 \mathrm{~m} 2$, pupuk K1: pupuk 7,5 kg / 5m2, pupuk K2: pupuk $15 \mathrm{~kg} / 5 \mathrm{~m} 2$ dan faktor kedua adalah pupuk NPK P(M) yang terdiri dari pupuk M0: NPK 0 g / 5m2, M1: Pupuk NPK 37,5 g / 5m2, M2: Pupuk NPK 75 g / 5m2 dan M3: Pupuk NPK 112,5 g / 5m2. Variabel yang diukur adalah Produksi Segar dan Rasio Daun dan Batang dari Penggundulan ketiga. Nilai Rataan hasil Produksi segar yg di dapat pada tiap perlakuan naik turun $\mathrm{K} 0 \mathrm{M} 0=6.71 \pm 0.112 . \mathrm{K} 0 \mathrm{M} 1=6.87 \pm 0.104, \mathrm{~K} 0 \mathrm{M} 2=6.82 \pm 0.042, \mathrm{~K} 0 \mathrm{M} 3=8.55$ $\pm 0.192, \mathrm{~K} 1 \mathrm{M} 0=7.33 \pm 0.440, \mathrm{~K} 1 \mathrm{M} 1=7.69 \pm 0.421, \mathrm{~K} 1 \mathrm{M} 2=7.91 \pm 0.170$, $\mathrm{K} 1 \mathrm{M} 3=7.339 .94 \pm 1.30, \mathrm{~K} 2 \mathrm{M} 0=9.35 \pm 0.280, \mathrm{~K} 2 \mathrm{M} 1=8.20 \pm 0.410, \mathrm{~K} 2 \mathrm{M} 2=$ $10.46 \pm 0.142, \mathrm{~K} 2 \mathrm{M} 3=11.21 \pm 0.205$. nilai rata-rata ratio daun batang $\mathrm{K} 0 \mathrm{M} 0=$ $3.65 \pm 0.12 . \mathrm{K} 0 \mathrm{M} 1=3.85 \pm 0.293, \mathrm{~K} 0 \mathrm{M} 2=4.22 \pm 0.083, \mathrm{~K} 0 \mathrm{M} 3=4.60 \pm 0.049$, $\mathrm{K} 1 \mathrm{M} 0=3.63 \pm 0.255, \mathrm{~K} 1 \mathrm{M} 1=4.75 \pm 0.202, \mathrm{~K} 1 \mathrm{M} 2=5.27 \pm 0.194, \mathrm{~K} 1 \mathrm{M} 3=0.63$ $5.43 \pm 0.140, \mathrm{~K} 2 \mathrm{M} 0=5.67 \pm 0.075, \mathrm{~K} 2 \mathrm{M} 1=5.64 \pm 0.110, \mathrm{~K} 2 \mathrm{M} 2=5.54 \pm 0.081$, $\mathrm{K} 2 \mathrm{M} 3=7.11 \pm 0.278$ Hasil analisis ragam menunjukkan bahwa aplikasi pupuk kandang signifikan $(\mathrm{P}<0,01)$ dan aplikasi pupuk NPK juga signifikan $(\mathrm{P}<0,05)$ pada Produksi Segar. Penerapan pupuk kandang terhadap rasio batang daun juga signifikan $(\mathrm{P}<0,05)$ dan aplikasi pupuk NPK juga signifikan $(\mathrm{p}<0,01)$. Hasil Interaksi antara pupuk kandang dan NPK memberikan pengaruh yang sangat nyata terhadap produksi segar dan ratio daun batang. Semakin tinggi dosis pupuk kandang dan NPK akan meningkatkan produksi segar dan ratio daun batang.
\end{abstract}

Kata kunci: Produksi segar, ratio daun batang, rumput odot,pupuk kandang, NPK

\section{ABSTRACT}

The purpose of this study was to examine the effect of applying manure and NPK fertilizer with the use of optimal fertilizer doses on odot grass. The materials used in this study were 720 stems of grass cuttings, $270 \mathrm{~kg}$ of manure, $2.5 \mathrm{~kg}$ of NPK fertilizer. The method used is factorial pattern experiments with random group designs. The first factor is manure consisting of KO fertilizer: $0 \mathrm{~kg} / 5 \mathrm{~m} 2$ fertilizer, 
Jurnal Sains Peternakan Nusantara

K1 fertilizer: $7.5 \mathrm{~kg} / 5 \mathrm{~m} 2$ fertilizer, K2 fertilizer: $15 \mathrm{~kg} / 5 \mathrm{~m} 2$ fertilizer and the second factor is NPK $(M)$ fertilizer consisting of MO fertilizer: $N P K 0 \mathrm{~g} / 5 \mathrm{~m} 2, \mathrm{M1}$ : NPK Fertilizer $37.5 \mathrm{~g} / 5 \mathrm{~m} 2$, M2: NPK Fertilizer $75 \mathrm{~g} / 5 \mathrm{~m} 2$ and M3: NPK Fertilizer $112.5 \mathrm{~g} / 5 \mathrm{~m} 2$. The measured variable is the Fresh Production and the Ratio of Leaves and Stems from the third Denudation. The average value of fresh production results obtained in each treatment up and down KOMO $=6.71 \pm 0.112$. $K O M 1=6.87 \pm 0.104, K O M 2=6.82 \pm 0.042, K O M 3=8.55 \pm 0.192, K 1 M O=7.33$ $\pm 0.440, K 1 M 1=7.69 \pm 0.421, K 1 M 2=7.91 \pm 0.170, K 1 M 3=7.339 .94 \pm 1.30$, $K 2 M O=9.35 \pm 0.280, K 2 M 1=8.20 \pm 0.410, K 2 M 2=10.46 \pm 0.142, K 2 M 3=$ $11.21 \pm 0.205$. The average value of the ratio of stem leaves. $K O M O=3.65 \pm 0.12$. $K O M 1=3.85 \pm 0.293, K O M 2=4.22 \pm 0.083, K 0 M 3=4.60 \pm 0.049, K 1 M 0=3.63$ $\pm 0.255, K 1 M 1=4.75 \pm 0.202, K 1 M 2=5.27 \pm 0.194, K 1 M 3=0.635 .43 \pm 0.140$, $K 2 M 0=5.67 \pm 0.075, K 2 M 1=5.64 \pm 0.110, K 2 M 2=5.54 \pm 0.081, K 2 M 3=7.11$ \pm 0.278 Results of the analysis of variance showed that the application of manure was significant $(P<0,01)$ and NPK fertilizer application were also significant $(P<0.05)$ in Fresh Production. The application of manure to the leaf stem ratio was also significant $(P<0.05)$ and the application of NPK fertilizer was also significant $(P<0.01)$. Results The interaction between manure and NPK has a very significant influence on fresh production and leaf stem ratio. The higher dose of manure and NPK will increase the fresh production and ratio of stem leaves

Keywords: Fresh production, leaf leaf ratio, odot grass, manure, NPK

\section{PENDAHULUAN}

Rumput gajah mini (Pennisetum purpureum cv. Mott) merupakan jenis rumput unggul dengan produktivitas dan kandungan zat gizi yang cukup tinggi serta memiliki palatabilitas yang tinggi bagi ternak ruminansia (Adi Fathul Qohar et al., 2019). Rumput tersebut dapat hidup di berbagai tempat, tahan lindungan, respon terhadap pemupukan, serta menghendaki tingkat kesuburan tanah yang tinggi (Sirait, 2017). Rumput gajah mini dikatakan rumput yang unggul dikarenakan mudah dibudidayakan (Hendarto et al., 2020).

Pupuk kandang merupakan pupuk yang cukup penting karena di dalamnya terdiri dari kotoran padat dan cair dari hewan ternak yang bercampur dengan sisa pakan sehingga dapat menambah unsur hara di dalam tanah (Hartatik \& Widowati, 2006). Beberapa sifat fisik tanah yang dapat di pengaruhi pupuk kandang antara lain kemantapan agregat, bobot volume, total ruang pori ratio daun batang, daya ikat air. Penggunaan pupuk merupakan suatu kebutuhan bagi setiap tanaman agar kebutuhan nutrisi terpenuhi dan menjaga keseimbangan unsure hara selama siklus pertumbuhan (Adi Fathul Qohar et al., 2021).

Pemberian pupuk organik dan anorganik (NPK) merupakan suatu usaha dalam memenuhi kebutuhan hara bagi tanaman (Qohar et al., 2020). Pemberian bahan organik dan anorganik dapat meningkatkan $\mathrm{pH}$ tanah, $\mathrm{N}$-total, P-tersedia dan K-tersedia di dalam tanah sehingga menigkatkan produksi tanaman (Sutejo, 2002). Berdasarkan 
uraian tersebut maka perlu dikaji mengenai kombinasi pupuk kandang dan NPK pada produksi segar dan ratio daun batang rumput gajah mini.

\section{METODOLOGI PENELITIAN}

Materi yang digunakan dalam penelitian adalah pupuk kandang $270 \mathrm{~kg}$, pupuk NPK 2,5 kg, tanaman rumput odot defoliasi ke-3 yang awalnya ditanam 720 batang stek rumput odot (jarak tanam $0,75 \mathrm{~m} \times 0,35 \mathrm{~m}$ ) dan luas per petak/unit $\left(5 \mathrm{~m}^{2}\right)$ sehingga lahan yang digunakan seluas $278 \mathrm{~m}^{2}$. Masing-masing unit terdiri dari 20 stek rumput odot. Materi lainnya yaitu pita ukur, patok bambu, cangkul, sabit, sekop, karung, plastik, counter,alat tulis. Metode penelitian adalah metode eksperimen menggunakan rancangan acak kelompok pola faktorial 3 x 4, dengan 12 kombinasi perlakuan. Masingmasing perlakuan diulang 3 kali. Faktor pertama adalah pupuk kandang dengan 3 level yaitu $\mathrm{K}_{0}$ : pupuk kandang $0 \mathrm{~kg} / 5 \mathrm{~m}^{2}, \mathrm{~K}_{1}$ : pupuk kandang $7,5 \mathrm{~kg} / 5 \mathrm{~m}^{2}, \mathrm{~K}_{2}$ : pupuk kandang $15 \mathrm{~kg} / 5 \mathrm{~m}^{2}$ dan faktor kedua adalah pupuk NPK (M) dengan 4 level yaitu $\mathrm{M}_{0}$ : pupuk NPK $0 \mathrm{~g} / 5 \mathrm{~m}^{2}, \mathrm{M}_{1}$ : pupuk NPK $37,5 \mathrm{~g} / 5 \mathrm{~m}^{2}, \mathrm{M}_{2}$ : pupuk NPK $75 \mathrm{~g} / 5 \mathrm{~m}^{2}$ dan $\mathrm{M}_{3}$ : pupuk NPK $112,5 \mathrm{~g} / 5 \mathrm{~m}^{2}$. Penelitian telah dilaksanakan di Experimental Farm dan Laboratorium Agrostologi Fakultas Peternakan, Universitas Jenderal Soedirman, Purwokerto. Peubah yang diamati dalam penelitian adalah produksi segar dan rasio daun batang. Data dianalisis statistik menggunakan analisis variansi dan diuji lanjut dengan orthogonal polynomial (Steel \& Torrie, 1994).

\section{HASIL DAN PEMBAHASAN}

\section{Pengaruh Kombinasi Pupuk Kandang dan NPK Terhadap Produksi Segar Rumput Gajah mini (Pennisetum purpureum cv. Mott)}

Hasil pengukuran Produksi Segar dari kombinasi pemberian pupuk kandang dengan NPK di dapat hasil nilai rata-rata yang meningkat. Hasil rataan terendah pada Produksi Segar terdapat pada perlakuan $\mathrm{K}_{0} \mathrm{M}_{0} 6,71 \pm 0.112 \mathrm{~kg}$, sedangkan rataan tertinggi

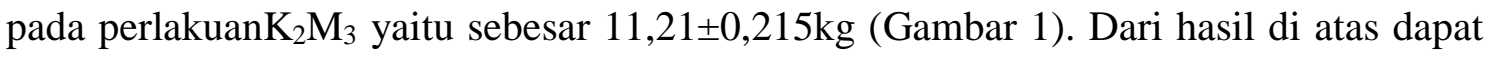
disimpulkan bahwa pemberian pupuk kandang dan NPK mempengaruhi produksi rumput gajah mini (pennisetum purporeum cv. Mott) menghasilkan ratan produksi yang tinggi. Nutrisi utama yang di butuhkan oleh tanaman adalah Nitrogen $(\mathrm{N})$, fosfor $(\mathrm{P})$, dan kalium (K). Hal ini sesuai dengan pendapat dari Firmansyah (2017) yang menyatakan bahwa funsi $\mathrm{N}, \mathrm{P}$ dan $\mathrm{K}$ sangat dibutuhkan dalam membantu proses fotosintesis dan produksi fotosintat yang dihasilkan, serta untuk meningkatkan pertumbuhan tanaman melalui mekanisme pengubahan dari unsur hara NPK menjadi senyawa organik atau energi yang disebut proses metabolisme. Menurut Kusuma (2014) pemupukan akan lebih efektif apabila menggunakan jenis pupuk yang tepat. 
Jurnal Sains Peternakan Nusantara Pengaruh Kombinasi Pupuk Kandang dan Npk Terhadap Produksi Segar dan Rasio Daun dan Batang

Rumput Gajah Mini Defoiasi Ke-3

EISSN: 2807-9361

Volume 01 Nomor 02 Desember 2021

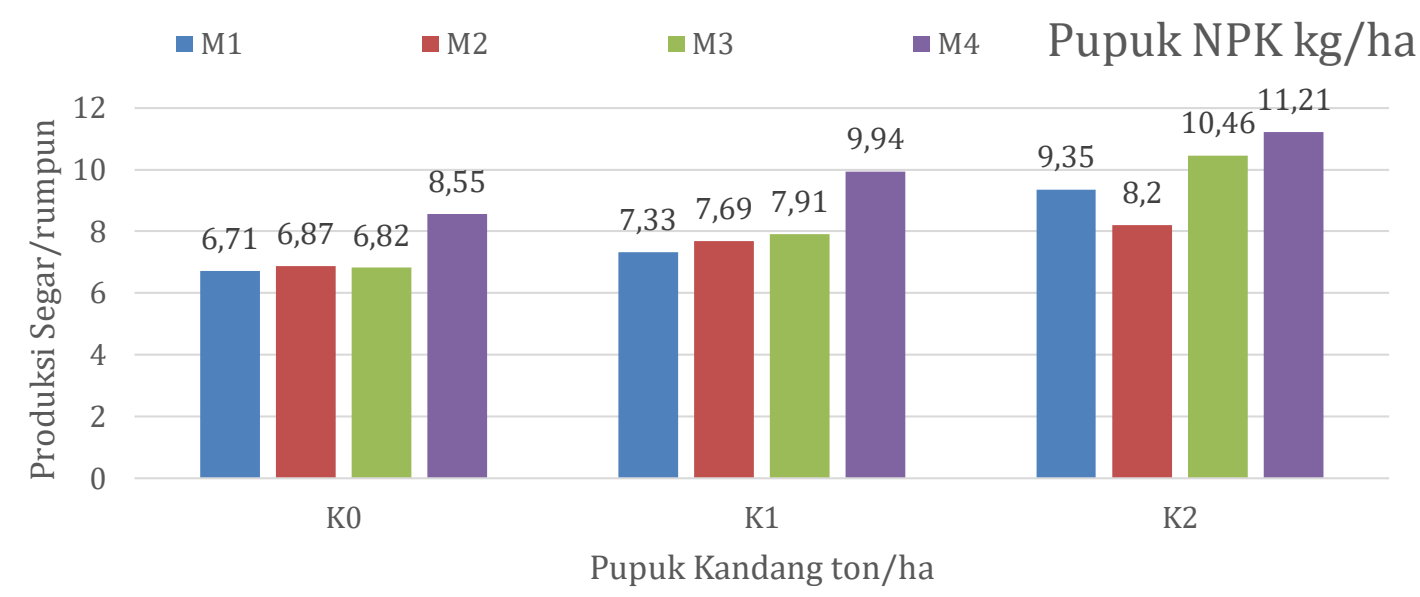

Gambar 1. Diargram kombinasi pupuk kandang dan NPK terhadap Produksi Segar

Hasil analisis variansi menunjukan bahwa pemberian pupuk kandang berpengaruh sangat nyata $(\mathrm{P}<0,01)$ terhadap produksi segar rumput gajah mini. Pemberian NPK juga berpengaruh nyata $(\mathrm{P}<0,05)$ terhadap Produksi Segar lihat Tabel 4. Hal tersebut di karenakan kandungan pupuk kandang dan NPK sangat berpengaruh dalam membantu proses metabolisme. Hal ini sesuai dengan Sumiati (2005) yang menyatakan bahwa nitrogen berfungsi sebagai pembangun asam nukleat, protein, bioenzim, dan klorofil sedangkan fosfor pembangun fosfolipid, asam nukleat,protein senyawa metabolik dan sebagai bagian dalam proses ATP dalam transfer energi, sedangkan kalium sebagai pengatur keseimbangan ion ion dalam sel yang berfungsi berbagai mekanisme metabolik.

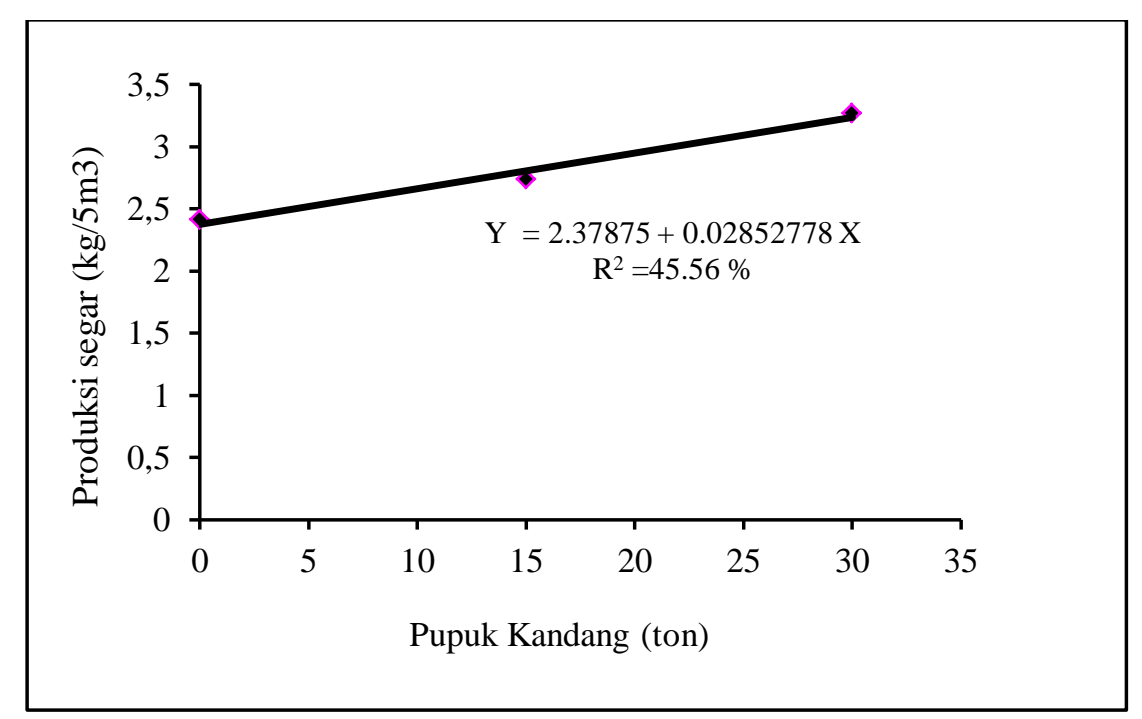

Gambar 2. Grafik hubungan antara dosis pupuk kandang dengan produksi segar rumput gajah mini. 
Hasil uji orthogonal polynomial (Gambar 2) menunjukkan bahwa dosis pemberian pupuk kandang berpengaruh linier terhadap produksi segar rumput gajah mini dengan persamaan $\mathrm{Y}=2,37875+0,02852778 \mathrm{X}$ dengaan koefesien regresi $\mathrm{R}^{2}=$ 45,56\% artinya kombinasi dosis pupuk kandang dan NPK yang berpengaruh terhadap Produksi Segar sebesar 45,56 \% sedangkan sisanya 54,44 \% dipengaruhi faktor lainnya. Hasil uji orthogonal polynomial (Gambar 3) menunjukkan bahwa dosis pemberian pupuk NPK berpengaruh kuadrater terhadap produksi segar rumput gajah mini dengan persamaan $\mathrm{Y}=2,5934444+0,0254667 \mathrm{X}+0,000025383 \mathrm{X}^{2}$ dengan koeefesian regresi $\mathrm{R}^{2}=33,88 \%$ artinya kombinasi dosis pupuk kandang dan NPK yang berpengaruh terhadap Produksi Segar sebesar 33,88 \% sedangkan sisanya 66,12 \% dipengaruhi faktor lainnya.

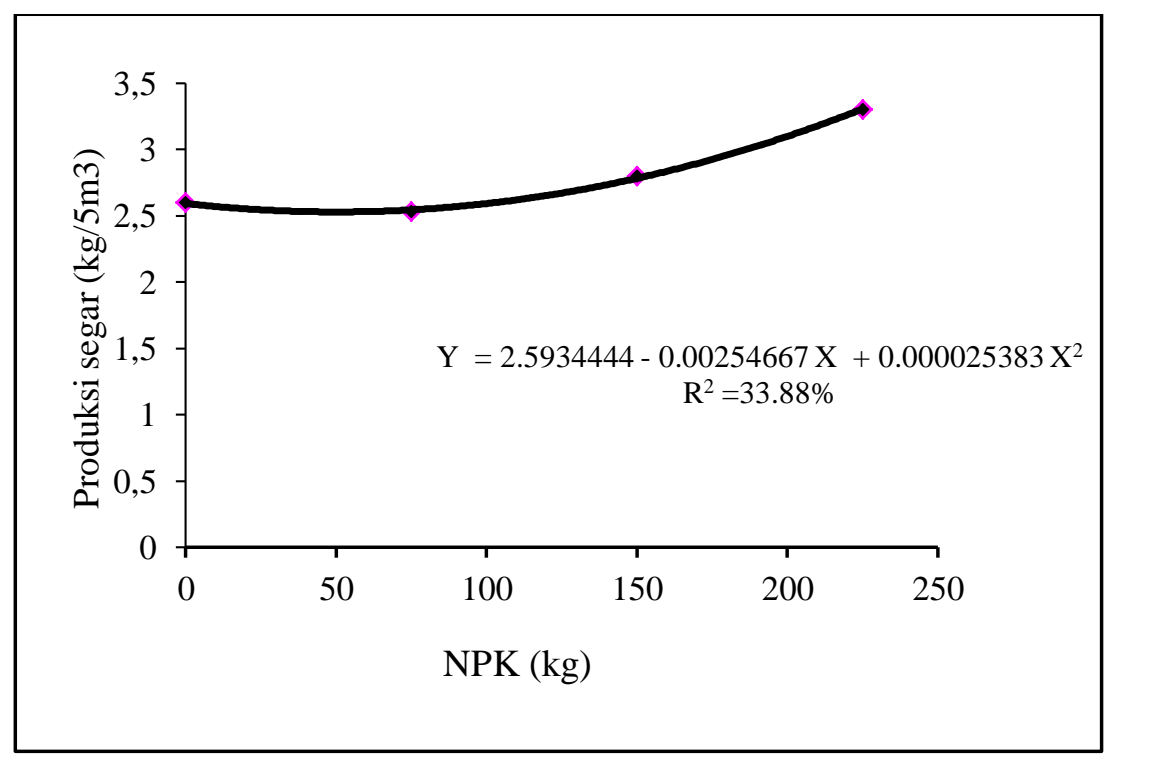

Gambar 3. Grafik hubungan antara dosis pupuk NPK dengan produksi segar rumput gajuı .......

\section{Pengaruh Kombinasi Pupuk Kandang dan NPK Terhadap Ratio Daun Batang Rumput Gajah mini (Pennisetum purpureum cv. Mott)}

Hasil rataan terendah dari ratio daun batang terdapat pada perlakuan K0M0 yaitu 3,65 $\pm 0,12$ di karenakan tidak diberikan pupuk kandang dan NPK. Sedangkan hasil rataan tertinggi terdapat pada perlakuan K2M3 yaitu 7,11 $\pm 0,278$ dikarenakan dilakukan penambahan pupuk kandang dan pupuk NPK (Gambar 4). Rumput gajah mini memiliki keunggulan dari rumput gajah lainnya yaitu pertumbuhannya yang cepat,berbulu halus, daun lembut,batangnya yang lunak serta disukai oleh ternak dan pertumbuhannya yang cepat. Hal tersebut sesuai dengan pendapat Sirait (2017) yang menyatakan bahwa rumput gajah mini memiliki ratio daun batang yang lebih tinggi senilai dengan 1,4 sedangkan rumput gajah lainnya 0,8 dan rasio tersebut menghasilkan produksi bahan kering senilai 25,42 ton/ha/tahun untuk rumput gajah mini sedangkan untuk rumput gajah lainnya menghasilkan 24,80ton/ha/tahun). 


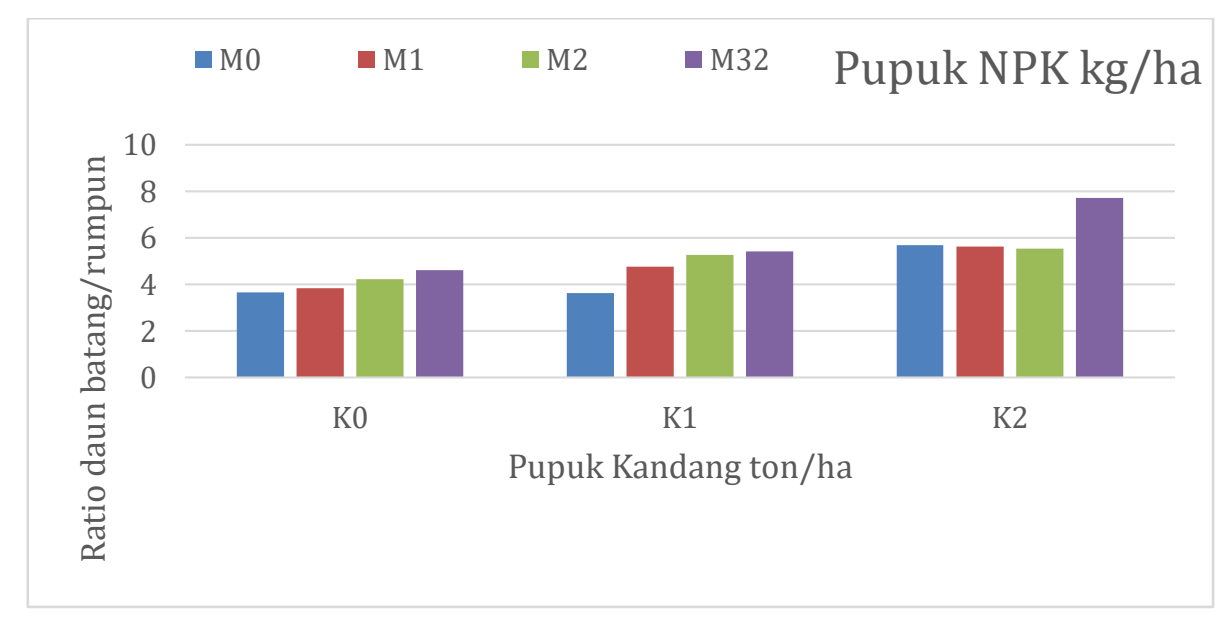

Gambar 4. Diargram kombinasi pupuk kandang dan NPK terhadap Ratio Daun Batang

Hasil analisis variansi menunjukan bahwa pemberian pupuk kandang berpengaruh sangat nyata $(\mathrm{P}<0,01)$ terhadap ratio daun batang rumput gajah mini. Sedangkan pemberian pupuk NPK berpengaruh nyata $(\mathrm{P}<0,05)$ terhadap ratio daun batang rumput gajah mini. Hal tersebut karena di dalam pupuk kandang maupun pupuk NPK terdapat unsur phospor berfungsi untuk pertumbuhan dan perkembangan tanaman. Hal ini sesuasi dengan pendapat Hardjowigeno (2003) yang menyatakan bahwa unsur fosfor penting untuk merangsang pertumbuhan akar, bahan dasar protein, proses fotosintesis, memperkuat batang tanaman serta membantu asimilasi dan respirasi tanaman.

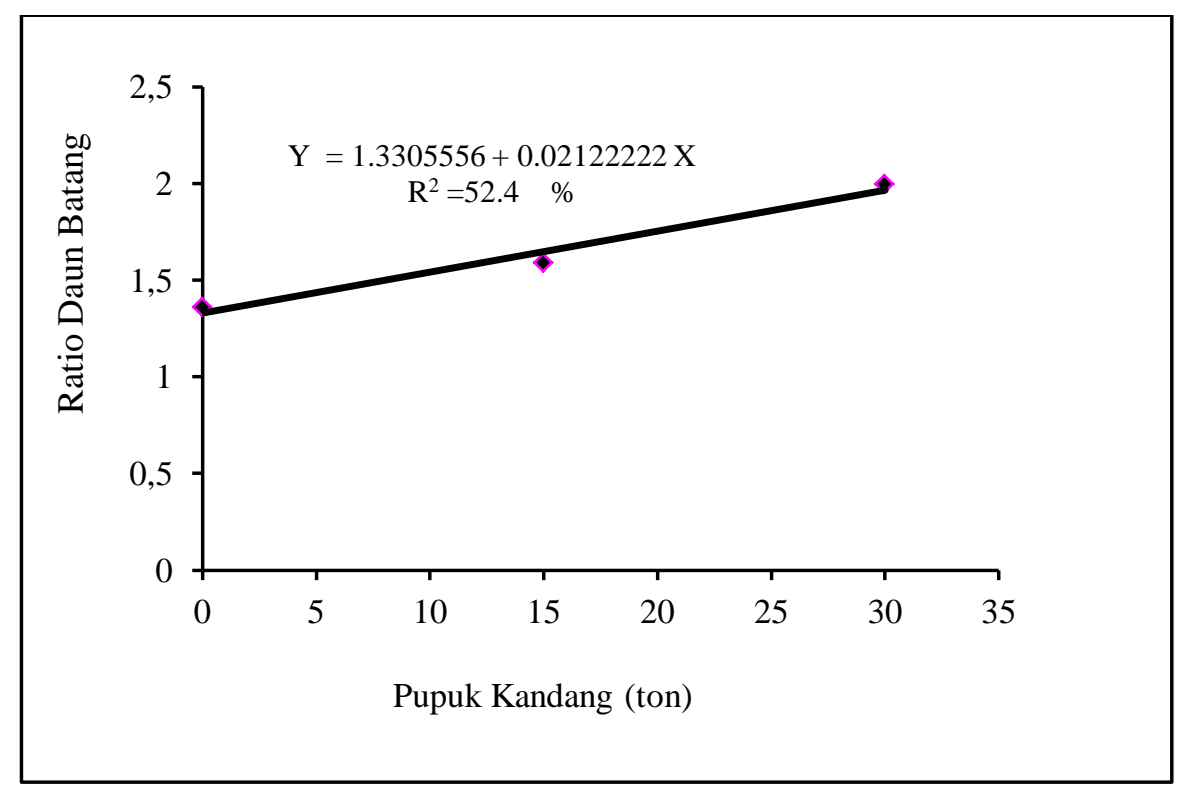

Gambar 5. Grafik hubungan antara dosis pupuk kandang dengan ratio daun batang rumput gajah mini 
Hasil uji orthogonal polynomial (Gambar 5) menunjukkan bahwa pemberian pupuk kandang berpengaruh secara linear terhadap ratio daun batang rumput gajah mini dengan persamaan $\mathrm{Y}=1,3305556+0,02122222 \mathrm{X}$ dengan koefisien determinasi $\left(\mathrm{R}^{2}\right)=$ $52,4 \%$ artinya dosis pupuk kandang yang berpengaruh terhadap ratio daun batang rumput gajah mini sebesar 52,4\% sedangkan sisanya $47,6 \%$ di pengaruhi oleh faktor lainnya. Jadi semakin tinggi pemberian pupuk kandang akan semakin meningkatan ratio daun batang. Hal ini sesuai dengan pendapat Dewi, (2017) unsur hara dalam tanah dapat disuplai dari pupuk kandang untuk memenuhi kebutuhan hara tanaman. Unsur hara digunakan ole tanaman yang berasal dari pupuk kandang untuk pertumbuhan dan perkembangan tanaman (Hanifa et al., 2012; Lasamadi et al., 2013; Mufarihin et al., 2012)

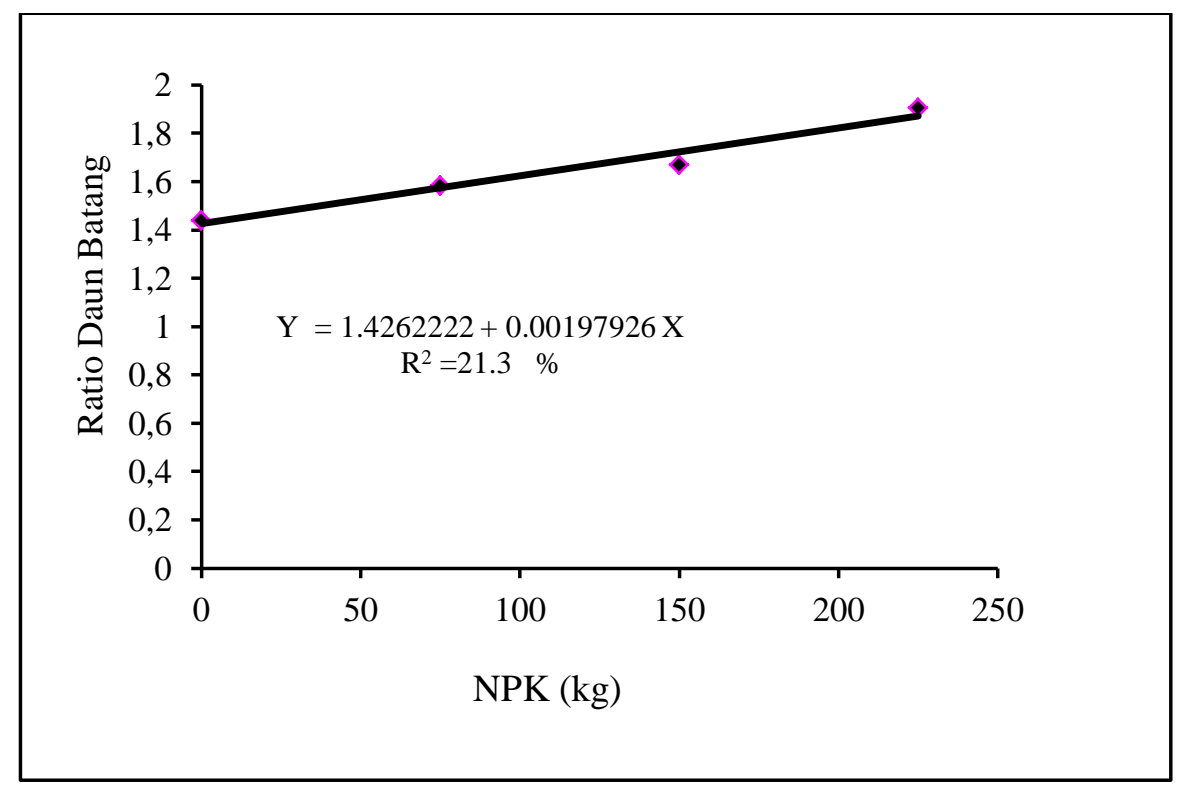

Gambar 6. Grafik hubungan antara dosis pupuk NPK dengan ratio daun batang gajah mini

Pemberian pupuk NPK berpengaruh secara linear terhadap ratio daun batang rumput gajah mini (Gambar 6) dengan persamaan $\mathrm{Y}=1,4262222+0,00197926 \mathrm{X}$ dengan koefisien determinasi $\left(\mathrm{R}^{2}\right)=21,3 \%$ artinya dosis pupuk NPK yang berpengaruh terhadap rasio daun dan batang sebesar $21,3 \%$ sedangkan sisanya 78,7 \% dipengaruhi oleh faktor lainnya.

\section{KESIMPULAN}

Interaksi antara pupuk kandang dan NPK tidak memberikan pengaruh yang nyata terhadap tinggi tanaman dan jumlah daun. Semakin tinggi level pupuk kandang dan NPK akan meningkatkan produksi segar dan ratio daun batang. 
Jurnal Sains Peternakan Nusantara Pengaruh Kombinasi Pupuk Kandang dan Npk Terhadap Produksi Segar dan Rasio Daun dan Batang

Rumput Gajah Mini Defoiasi Ke-3

EISSN: 2807-9361

\section{DAFTAR PUSTAKA}

Volume 01 Nomor 02 Desember 2021

Dewi, D. P. rukaman. (2017). Produksi Rumput (Pennisetum purpureum cv. Mott) Defoliasi I Pertama Dengan Jenis Pupuk Yang Berbeda. AVES: Jurnal Ilmu Peternakan, 11(2), 7. https://doi.org/10.35457/aves.v11i2.280

Firmansyah. I, Syakir, M. dan Lukman, L. (2017). Pengaruh Kombinasi Pupuk Dosis Pupuk N P Dan K Terhadap Pertumbuhan Dan Hasil Tanam Terung (Solanum melongenal.) Jurnal Horticultura. 27(1)

Hardjowigeno S. (2003). Ilmu Tanah. Akademika Pressindo. Bogor.

Hanifa, A., Subagyo, Y. B. P. \& Lutojo. (2012). Karakteristik Morfologi Rumput Gajah dan Raja Di Tanah Vulkanik Dengan Pemberian Bahan Organik. Buana Sains, 12(1), $39-44$.

Hartatik, W. \& Widowati, L. . (2006). Pupuk Kandang. In Pupuk Organik dan Pupuk Hayati (pp. 59-82).

Hendarto, E., Qohar, A. F., Hidayat, N., Bahrun, B. \& Harwanto, H. (2020). Produksi Dan Daya Tampung Rumput Odot (Pennisetum purpureum cv. Mott) Pada Berbagai Kombinasi Pupuk Kandang Dan NPK. Prosiding Seminar Teknologi Dan Agribisnis Peternakan VII-Webinar: Prospek Peternakan Di Era Normal Baru Pasca Pandemi COVID-19, 7(7), 751-758.

Kusuma, M. E. (2014). Respon Rumput Gajah (Pennisetum purpureum) Terhadap Pemberian Pupuk Majemuk Respons of Elephant Grass (Pennisetum purpureum) with The Application of Compound Fertilizer. Jurnal Ilmu Hewani Tropika, 3(1), 6-11. https://doi.org/10.1115/1.4003522

Lasamadi, R. D., Malalantang, S. S., Rustandi \& Anis, S. D. (2013). Pertumbuhan Dan Perkembangan Rumput Gajah Dwarf (Pennisetum purpureum cv. Mott) Yang Diberi Pupuk Organik Hasil Fermentasi EM4. ZOOTEC, 32(5), 158-171. https://doi.org/10.35792/zot.32.5.2013.984

Mufarihin, A., Lukiwati, D. R. \& Sutarno. (2012). Pertumbuhan dan Bobot Bahan Kering Rumput Gajah dan Rumput Raja pada Perlakuan Aras Auksin yang Berbeda. Jurnal Animal Agriculture, 1(2), 1-15.

Qohar, A. F., Hendarto, E. \& Munasik, M. (2020). Pertumbuhan Rumput Raja (Pennisetum purpureophoides) Defoliasi Kedua Akibat Pemupukan Kompos yang Diperkaya dengan Azolla microphylla. Prosiding Seminar Nasional Pembangunan Dan Pendidikan Vokasi Pertanian, 1(1), 1-9. https://doi.org/10.47687/snppvp.v1i1.120

Qohar, Adi Fathul, Hendarto, E., Hidayat, N., Bahrun, Harwanto \& Nuraeni, N. (2021). Pengaruh Kombinasi Dosis Pemupukan Kompos Organik Dan Penambahan Azolla Terhadap Pertumbuhan Rumput RajA. Jurnal Sains Peternakan Nusantara, 01(01), 1- 
Jurnal Sains Peternakan Nusantara Pengaruh Kombinasi Pupuk Kandang dan Npk Terhadap Produksi Segar dan Rasio Daun dan Batang

Rumput Gajah Mini Defoiasi Ke-3 EISSN: 2807-9361

12. Volume 01 Nomor 02 Desember 2021

Qohar, Adi Fathul, Hidayat, N. \& Bahrun, B. (2019). Pengaruh Kombinasi Pupuk Kandang Dan NPK Terhadap Tinggi Tanaman Dan Jumlah Daun Rumput Odot (Pennisetum purpureum cv. Mott). Journal of Livestock and Animal Production, 2(1), $1-7$.

Sirait, J. (2017). Rumput Gajah Mini ( Pennisetum purpureum cv . Mott ) sebagai Hijauan Pakan untuk Ruminansia. Wartazoa, 27(4), 167-176. https://doi.org/http://dx.doi.org/10.14334

Steel, R. G. D. and \& Torrie, J. H. (1994). Principle and Procedures of Statistics: A Biometrical Approach (Terjemahan : B. Soemantri (ed.)). PT. Gramedia Pustaka Utama. Sutejo, M. M. (2002). Pupuk dan Cara Pemupukan (Cetakan ke). Rineka Cipta. Jakarta. Sumiati, E. (2005). Pertumbuhan dan Hasil Kentang Dengan Aplikasi NPK 15-15-15 dan Pupuk Pelengkap Cair Di Dataran Tinggi. J. Horticultura.15 (4),270-8 